Keywords: MURR Fuel, $\mathrm{H}$ Canyon, Aluminum Dissolution, Off-site Fuel

Retention: Permanent

\title{
Dissolution of Irradiated MURR Fuel Assemblies -Effect of Increased Purge Rate and Catalyst Concentration on the Batch Size
}

E.A. Kyser

July 2010

Savannah River National Laboratory Savannah River Nuclear Solutions Aiken, SC 29808

Prepared for the U.S. Department of Energy under contract number DE-AC09-08SR22470.

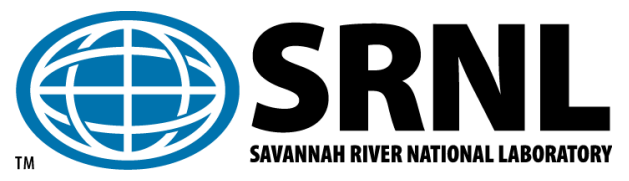




\section{DISCLAIMER}

This work was prepared under an agreement with and funded by the U.S. Government. Neither the U.S. Government or its employees, nor any of its contractors, subcontractors or their employees, makes any express or implied:

1. warranty or assumes any legal liability for the accuracy, completeness, or for the use or results of such use of any information, product, or process disclosed; or

2. representation that such use or results of such use would not infringe privately owned rights; or

3. endorsement or recommendation of any specifically identified commercial product, process, or service.

Any views and opinions of authors expressed in this work do not necessarily state or reflect those of the United States Government, or its contractors, or subcontractors.

\section{Printed in the United States of America}

Prepared for

U.S. Department of Energy 


\section{REVIEWS AND APPROVALS}

AUTHORS:

original approved by E. A. Kyser III on 7/22/2010

E. A. Kyser Date

Separations and Actinide Science Programs

TECHNICAL REVIEW:

original approved by James E. Laurinat on 7/22/2010

J. E. Laurinat Date,

Process Modeling and Computational Sciences

APPROVAL:

original approved by Samuel D. Fink on 7/26/2010

S. D. Fink, Manager Date

Separations and Actinide Science Programs

original approved by Sharon L. Marra on 7/26/2010

S. L. Marra, Manager Date

Environmental \& Chemical Process Technology Research Programs

original approved by W. G. Dyer on 8/2/2010

W. G. Dyer, Manager

Date

H-Canyon Technical Support 
SRNL-STI-2010-00205, Rev 0 


\section{Table of Contents}

Table of Contents ...

Table of Figures: .. V

Table of Tables:

SUMMARY

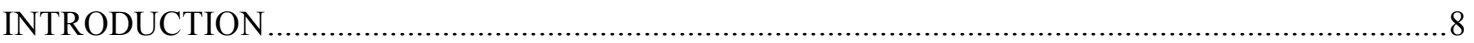

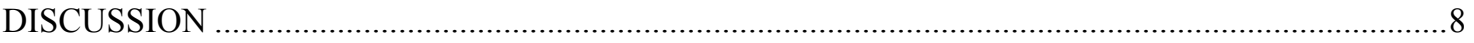

Required Purge Rate as a Function of Off-gas Rate:......................................................... 11

Number of Fuel Bundles in the Initial Charge to the Dissolver: ...................................................12

Number of Fuel Bundles in the Second Charge to the Dissolver: .................................................13

Effect of Increasing the Catalyst Concentration on a Subsequent Charge: ........................................15

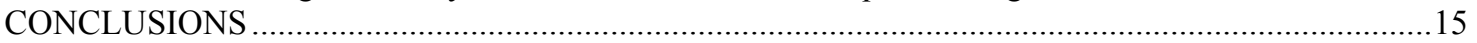

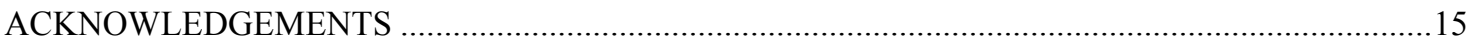

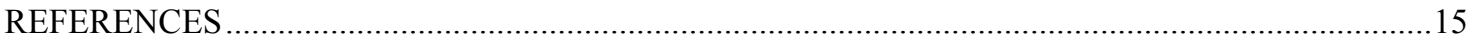

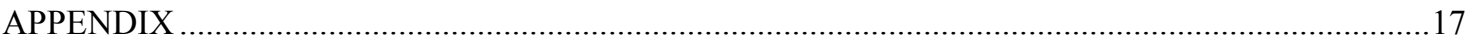




\section{Table of Figures:}

Figure 1. Off-gas Concentrations Observed during the Dissolution of Aluminum Clad Fuel. ....... 9

Figure 2. Flammability Data for the Hydrogen-Nitric Oxide-Nitrous Oxide-Air System at $28{ }^{\circ} \mathrm{C} . ~ 99$

Figure 3. Effect of Aluminum Nitrate Concentration on the Dissolution Rate Characteristics of Fuel Elements (Aluminum - 16 wt \% Uranium Alloy).

Figure 4. Effect of Aluminum Dissolution and Nitric Acid Consumption on the Dissolution Rate.

\section{Table of Tables:}

Table 1. LFL Data at NO/ $\mathrm{N}_{2} \mathrm{O}$ Molar Ratio Equal to 2.57. .................................. 9

Table 2. Effect of the Number of MURR Bundles Charged on the Aluminum and Uranium Concentration (upper bounding solution volume).

Table 3. Effect of the Number of MURR Bundles Charged on the Aluminum and Uranium Concentration (minimal solution volume).

Table 4. Effect of Purge Rate Dilution on Off-Gas Composition (40 scfm minimum purge rate). ..11

Table 5. Effect of Purge Rate Dilution on Off-Gas Composition. ............................... 12

Table 6. Calculated Areas and Peak Off-gas rates for an Initial Dissolver Charge of Five Bundles. 12

Table 7. Calculated Outer Bundle Areas and Peak Off-gas Rates for an Initial Dissolver Charge. . 12

Table 8. Effect of Catalyst and Aluminum Concentration on the Size of a Fuel Charge for Various Purge Rates.

Table 9. Effect of the Number of MURR Bundles Charged on the Aluminum and Uranium Concentration (14000 L solution volume).

Table 10. Effect of the Number of MURR Bundles Charged on the Aluminum and Uranium Concentration (13000 L solution volume).

Table 11. Effect of the Number of MURR Bundles Charged on the Aluminum and Uranium Concentration (7500 L solution volume).

Table 12. Effect of the Number of MURR Bundles Charged on the Aluminum and Uranium Concentration (7000 L solution volume).

Table 13. Effect of the Number of MURR Bundles Charged on the Aluminum and Uranium Concentration (6500 L solution volume).

Table 14. Effect of the Number of MURR Bundles Charged on the Aluminum and Uranium Concentration (6000 L solution volume). 


\title{
Dissolution of Irradiated MURR Fuel Assemblies - Effect of Increased Purge Rate and Catalyst Concentration on the Batch Size
}

\author{
by \\ Edward A. Kyser \\ Savannah River National Laboratory \\ Environmental and Chemical Technology Directorate
}

July 22,2010

\begin{abstract}
SUMMARY
Flowsheets for the dissolution of aluminum-clad spent nuclear fuel have been proposed using $0.002 \mathrm{M}$ mercuric nitrate catalyst in 5 to $6 \mathrm{M}$ nitric acid. Previous calculations for flammable gas control during the dissolution of spent nuclear fuel have been extended to cover a range of dissolver purge rates from 40 to $55 \mathrm{scfm}$. A range of dissolver solution volumes from 12000 to 15000 liters were considered for the large H-Canyon dissolver (6.4D). Depending on the purge rate, anywhere from four to six bundles of MURR fuel can be initially charged to the dissolver (6.4D). For successive charges where the dissolver solution already contains $0.002 \mathrm{M}$ mercury catalyst and the dissolved aluminum from five bundles of MURR fuel, five to nine bundles of additional fuel can be charged depending on the purge rate and the dissolver solution volume.
\end{abstract}

Similar calculations have been performed for the small H-Canyon dissolver (6.1D) for solution volumes that ranged from 6000 to 7500 liters and purge rates from 40 to $55 \mathrm{scfm}$. The limitations on the initial charge are four to six bundles depending on the purge rate. The aluminum from four bundles of fuel in an initial charge will allow nine to ten bundles in the second charge to 6.1D depending on the purge rate and dissolver solution volume. Solubility or criticality limitations will restrict the second charge on the small dissolver.

The concentration of aluminum from previous charges will slow the dissolution rate to extend the cycle time of repeated charges of fuel. Calculations have been performed to allow a second catalyst addition (up to $0.004 \mathrm{M}$ total catalyst) to reduce the cycle time (as necessary) based on the aluminum concentration and the purge rate. 


\section{INTRODUCTION}

$\mathrm{H}$-Canyon is preparing to resume processing of off-site aluminum-clad spent nuclear fuel (SNF). The Savannah River Site (SRS) has historically received aluminum-clad SNF from research reactors and processed these fuels in H-Canyon. The initial fuel type planned for processing is irradiated SNF assemblies from the University of Missouri Research Reactor (MURR). A recent report ${ }^{1}$ reviewed the history of the dissolution of irradiated MURR fuel and provided a basis for processing that fuel in the future. Due to flammability limitations in the off-gas system that restricted the dissolution batch size, $\mathrm{H}$-Canyon requested that SRNL evaluate the effect that proposed increases in the off-gas purge rates would have on the amount of fuel that could be safely charged to the dissolver ${ }^{2}$.

Previous, calculations showed that a credited purge rate of $40 \mathrm{scfm}$ would restrict the dissolver batch size to no more than four bundles of MURR fuel in an initial charge ${ }^{1}$. Depending on volume and concentration constraints, the initial charge could be followed by a second charge of up to five bundles to the same dissolver batch for the nominal $13000 \mathrm{~L}$ dissolver. In the previous report, it was noted that a modest increase in the purge rate $(\sim 10 \%)$ would allow additional bundle(s) of fuel to be added to each charge.

H-Canyon requested that SRNL evaluate the effect of purge rate of up to $55 \mathrm{scfm}$ on the number of bundles allowed in each charge. They also requested a basis for the use of additional mercury catalyst during the second charge (as a second catalyst addition) to reduce the cycle time.

\section{DISCUSSION}

The details of the dissolution process and description of the MURR fuel were thoroughly discussed in a previous study ${ }^{1}$ and will only be summarized here as necessary to extend the calculations. For additional discussion on the scaling of each of the parameters which affect the dissolution rate or purge requirements refer to the previous report or the original references as provided by that report.

Fundamentally, the dissolution rate is controlled by the concentrations of nitric acid, mercury catalyst, dissolved aluminum, and the effective submerged surface area. The initial nitric acid concentration should be determined based on the moles of aluminum and uranium metal to be dissolved while arriving at a terminal nitric acid concentration of $\sim 0.5 \mathrm{M}$ nitric acid after the complete dissolution of the last charge (assuming 3.75 mole of nitric acid consumed per mole of aluminum dissolved and 4 mole of nitric acid consumed per mole of uranium dissolved). The concentration of aluminum at the beginning of each dissolver batch is assumed to be minimal (due only to aluminum in the heel of the previous batch). It is assumed that the maximum dissolution rate (where the purge requirements are the highest) will occur early in the initial dissolver charge (as the catalyst addition is completed), and will be primarily determined by the amount of catalyst present, the nitric acid concentration and the effective surface area of the fuel bundles. The metered addition of mercury catalyst as a function of time allows significant aluminum to dissolve into solution prior to the catalyst addition being completed, thus results in a lower the peak off-gas rate. Depending on the dissolution rate during catalyst addition and the length of time taken to add the catalyst, sufficient aluminum will dissolve to control the dissolution rate during the middle stage of dissolution of the initial charge. 


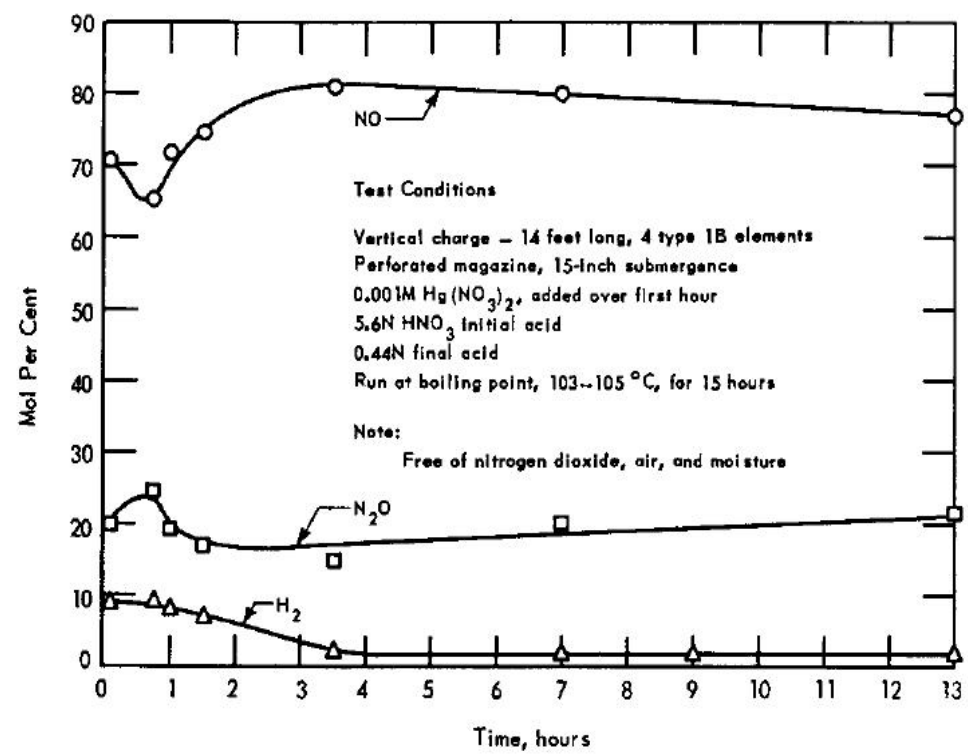

Figure 1. Off-gas Concentrations Observed during the Dissolution of Aluminum Clad Fuel ${ }^{3}$.

The dissolution of aluminum clad fuel primarily generates nitric oxide (NO) along with nitrous oxide $\left(\mathrm{N}_{2} \mathrm{O}\right)$, nitrogen dioxide $\left(\mathrm{NO}_{2}\right)$, nitrogen and hydrogen. The composition of the off-gas varies over time with the highest concentration of hydrogen observed during the initial few hours of the dissolution cycle ${ }^{3}$ (see Figure 1). A dissolution off-gas composition of $7.0 \mathrm{vol} \% \mathrm{H}_{2}, 71.38 \mathrm{vol} \% \mathrm{NO}$ and $21.62 \mathrm{vol} \% \mathrm{~N}_{2} \mathrm{O}$ on an air, water and nitrogen dioxide-free basis is assumed to be bounding for this process ${ }^{4}$. The initial few hours of dissolution also coincides with the period of highest dissolution rate ${ }^{3}$. Potential flammable concentrations of hydrogen that are produced are diluted with air by a dissolver purge stream. The data of $\mathrm{Scott}^{5}$ at an $\mathrm{NO} / \mathrm{N}_{2} \mathrm{O}$ ratio equal to 2.57 was used to determine the composition-specific lower flammability limit (LFL) (Table 1 and Figure 2). As discussed in the previous report, the LFL for $\mathrm{NO} / \mathrm{N}_{2} \mathrm{O}$ molar ratio equal to 2.57 should be a lower bounding limit for the actual process off-gas ${ }^{1}$ The process off-gas varies between $\mathrm{NO} / \mathrm{N}_{2} \mathrm{O}$ molar ratios of 2.7 to 5 . The LFL values are temperature corrected to $200{ }^{\circ} \mathrm{C}$ since that is the operating condition in the iodine reactor through which the off-gas stream flows.

The dissolution rate (and off-gas generation rate) varies linearly with both the mercury catalyst and the nitric acid concentrations ${ }^{1}$. Dissolved aluminum decreases the rate in an inverse logarithmic relationship. For these calculations it is assumed (based on the observations of Caracciolo ${ }^{3}$ ) that the dissolution rate of the fuel scales with the outer area of the submerged portion of the fuel bundles. After

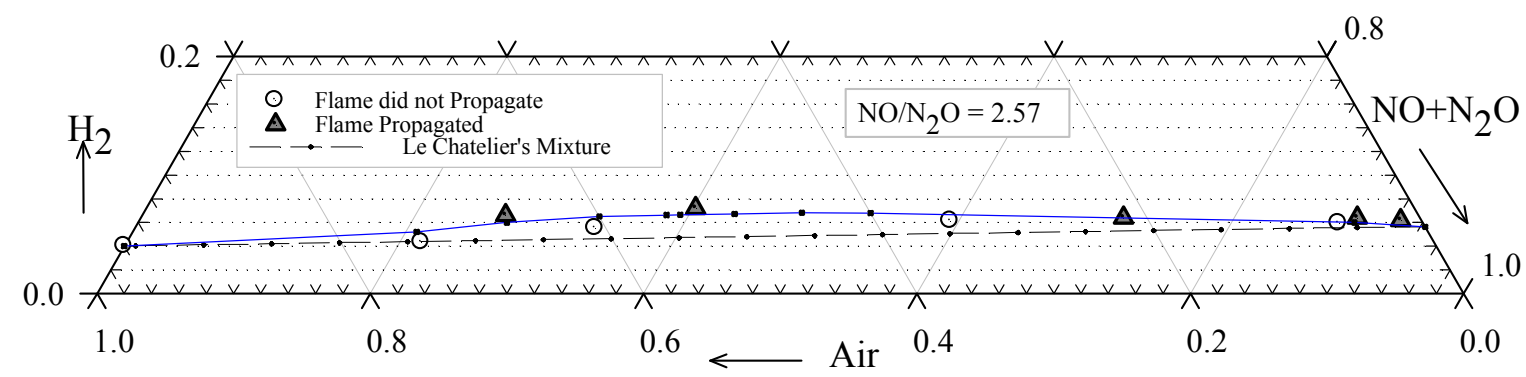

Figure 2. LFL Flammability Data for the Hydrogen-Nitric Oxide-Nitrous Oxide-Air System at $28{ }^{\circ} \mathrm{C}$. 
Table 2. Effect of the Number of MURR Bundles Charged on the Aluminum and Uranium Concentration (upper bounding solution volume).

\begin{tabular}{cccccccc}
\hline $\begin{array}{c}\text { Vol } \\
\mathrm{L}\end{array}$ & Bundles & $\begin{array}{c}\mathrm{Al} \\
\mathrm{kg}\end{array}$ & $\begin{array}{c}\mathrm{U} \\
\mathrm{Kg}\end{array}$ & $\begin{array}{c}\mathrm{Al} \\
\mathrm{M}\end{array}$ & $\begin{array}{c}{ }^{235} \mathrm{U} / \mathrm{L} \\
{ }^{235} \mathrm{U}\end{array}$ & $\begin{array}{c}\mathrm{HNO}^{3} \\
\mathrm{M}^{\mathrm{c}}\end{array}$ \\
\hline 15000 & 1 & 28.5 & 3.3 & 0.070 & 0.21 & 0.16 & 0.77 \\
15000 & 2 & 56.9 & 6.6 & 0.141 & 0.41 & 0.33 & 1.04 \\
15000 & 3 & 85.4 & 10.0 & 0.211 & 0.62 & 0.49 & 1.30 \\
15000 & 4 & 114 & 13.3 & 0.281 & 0.82 & 0.66 & 1.57 \\
15000 & 5 & 142 & 16.6 & 0.352 & 1.03 & 0.82 & 1.84 \\
15000 & 6 & 171 & 19.9 & 0.422 & 1.24 & 0.99 & 2.11 \\
15000 & 7 & 199 & 23.3 & 0.492 & 1.44 & 1.15 & 2.37 \\
15000 & 8 & 228 & 26.6 & 0.563 & 1.65 & 1.32 & 2.64 \\
15000 & 9 & 256 & 29.9 & 0.633 & 1.85 & 1.48 & 2.91 \\
15000 & 10 & 285 & 33.2 & 0.704 & 2.06 & 1.65 & 3.18 \\
15000 & 11 & 313 & 36.6 & 0.774 & 2.27 & 1.81 & 3.44 \\
15000 & 12 & 342 & 39.9 & 0.844 & 2.47 & 1.98 & 3.71 \\
15000 & 13 & 370 & 43.2 & 0.915 & 2.68 & 2.14 & 3.98 \\
15000 & 14 & 399 & 46.5 & 0.985 & 2.89 & 2.31 & 4.25 \\
15000 & 15 & 427 & 49.9 & 1.055 & 3.09 & 2.47 & 4.51 \\
15000 & 16 & 456 & 53.2 & 1.126 & 3.30 & 2.64 & 4.78 \\
15000 & 17 & 484 & 56.5 & 1.196 & 3.50 & 2.80 & 5.05 \\
\hline
\end{tabular}

${ }^{\mathrm{a}}$ Assumes $6.8 \mathrm{~kg} \mathrm{Al} / \mathrm{bundle}+5.418 \mathrm{~kg} \mathrm{Al} / \mathrm{assembly,} 4$ assemblies/bundle.

${ }^{\mathrm{b}}$ Post irradiation values assuming $20 \%$ burn-up of ${ }^{235} \mathrm{U}$.

${ }^{\mathrm{c}}$ Initial acid required: $0.5 \mathrm{M}$ excess acid, 3.75 moles of acid consumed per mole of Al, 4 moles of acid consumed per mole of $\mathrm{U}$.

Table 3. Effect of the Number of MURR Bundles Charged on the Aluminum and Uranium Concentration (minimal solution volume).

\begin{tabular}{|c|c|c|c|c|c|c|c|}
\hline $\begin{array}{c}\text { Vol } \\
\mathrm{L} \\
\end{array}$ & Bundles & $\begin{array}{c}\mathrm{Al} \\
\mathrm{kg}^{\mathrm{a}} \\
\end{array}$ & $\begin{array}{r}\mathrm{U} \\
\mathrm{kg}\end{array}$ & $\begin{array}{l}\mathrm{Al} \\
\mathrm{M} \\
\end{array}$ & $\begin{array}{c}{ }^{235} U \\
g / L\end{array}$ & $\begin{array}{l}{ }^{235}{ }^{\mathrm{g} / \mathrm{L}^{\mathrm{b}}} \\
\end{array}$ & $\begin{array}{c}\mathrm{HNO}_{3} \\
\mathrm{M}^{\mathrm{c}}\end{array}$ \\
\hline 12000 & 1 & 28.5 & 3.3 & 0.088 & 0.26 & 0.21 & 0.83 \\
\hline 12000 & 2 & 56.9 & 6.6 & 0.176 & 0.52 & 0.41 & 1.17 \\
\hline 12000 & 3 & 85.4 & 10.0 & 0.264 & 0.77 & 0.62 & 1.50 \\
\hline 12000 & 4 & 114 & 13.3 & 0.352 & 1.03 & 0.82 & 1.84 \\
\hline 12000 & 5 & 142 & 16.6 & 0.440 & 1.29 & 1.03 & 2.17 \\
\hline 12000 & 6 & 171 & 19.9 & 0.528 & 1.55 & 1.24 & 2.51 \\
\hline 12000 & 7 & 199 & 23.3 & 0.616 & 1.80 & 1.44 & 2.84 \\
\hline 12000 & 8 & 228 & 26.6 & 0.704 & 2.06 & 1.65 & 3.18 \\
\hline 12000 & 9 & 256 & 29.9 & 0.791 & 2.32 & 1.85 & 3.51 \\
\hline 12000 & 10 & 285 & 33.2 & 0.879 & 2.58 & 2.06 & 3.84 \\
\hline 12000 & 11 & 313 & 36.6 & 0.967 & 2.83 & 2.27 & 4.18 \\
\hline 12000 & 12 & 342 & 39.9 & 1.055 & 3.09 & 2.47 & 4.51 \\
\hline 12000 & 13 & 370 & 43.2 & 1.143 & 3.35 & 2.68 & 4.85 \\
\hline 12000 & 14 & 399 & 46.5 & 1.231 & 3.61 & 2.89 & 5.18 \\
\hline 12000 & 15 & 427 & 49.9 & 1.319 & 3.86 & 3.09 & 5.52 \\
\hline 12000 & 16 & 456 & 53.2 & 1.407 & 4.12 & 3.30 & 5.85 \\
\hline 12000 & 17 & 484 & 56.5 & 1.495 & 4.38 & 3.50 & 6.19 \\
\hline
\end{tabular}

the bundle is consumed, the dissolution rate of the fuel assemblies itself is assumed to scale with the outer area of the submerged portion of the assemblies. For this process the dissolver is heated to boiling and the catalyst is added at a steady rate over at least a one-hour period of time. The gradual addition of catalyst slows the initial dissolution rate and allows a significant quantity of aluminum to dissolve prior to completion of the catalyst addition. The peak off-gas generation rate is thus reduced allowing a larger amount of fuel to be charged in the initial charge. The amount of fuel allowed is calculated based on the initial conditions and the peak off-gas generation rate as determined by Kyser ${ }^{1}$ from Caracciolo's measurements ${ }^{3}$ and scaled by the outer surface area of the fuel bundle.

For multiple charge dissolutions, the dissolution rate will be significant during the time that the dissolver solution is heated but not yet at temperature because the catalyst is already present in the solution (as compared to the initial charge). The purge requirements are calculated crediting the suppression effect that the dissolved aluminum has on the dissolution rate, allowing additional fuel bundles to be included in the charge. The concentration of aluminum in the dissolver is determined by the number of fuel bundles dissolved in the initial charge and the volume of solution in the dissolver. Table 2 shows the expected concentrations of aluminum and uranium for assumed upper expected volume $(15000 \mathrm{~L})$ in the 6.4D canyon dissolver. Table 3 shows the same values for the volume calculated at a minimal operating volume (12000 L) of the dissolver. A solution volume change from $12000 \mathrm{~L}$ to $15000 \mathrm{~L}$ changes the aluminum concentration from $0.44 \mathrm{M}$ to $0.35 \mathrm{M}$ for an initial charge of five bundles. Additional tables calculated at different dissolver solution volumes are included in the appendix as Tables 10 through 15. 


\section{Required Purge Rate as a Function of Off-gas Rate:}

$\mathrm{H}-\mathrm{Canyon}$ has historically operated the fuel dissolution process by establishing a minimum purge rate for dilution of the hydrogen in the process off-gas. The dissolvers are allowed to operate up to $60 \%$ of the LFL due to the use of active engineered controls (Dissolver Low Air Sparge and Purge Air/Steam Flow Interlocks) which shut off the flow of steam to the dissolver coils. Since the iodine reactor in the off-gas stream is heated to $200{ }^{\circ} \mathrm{C}$, the basis of minimum purge rate is set at $60 \%$ of the LFL at $200{ }^{\circ} \mathrm{C}$. Temperature attenuation (adjustment) of the LFL from 28 to $200{ }^{\circ} \mathrm{C}$ is performed using a formula taken from the literature (Burgess-Wheeler Law) and described in a report by Dyer ${ }^{6}$. Various temperature coefficients are reported in the literature but the value of $0.0011 /{ }^{\circ} \mathrm{C}$ for the relative change in the LFL of hydrogen in air $^{7,8}$ appears to be the most appropriate for the assumed gas mixture. Table 4 shows the calculated dilution effect that a $40 \mathrm{scfm}$ purge has on the assumed off-gas composition at various peak off-gas rates. The LFL is estimated using the $\mathrm{NO} / \mathrm{N}_{2} \mathrm{O}$ molar ratio equal to 2.57 data from $\operatorname{Scott}^{5}$ (i.e., numerical values evaluated from Scott's data included as Table 1).

Table 4. Effect of Purge Rate Dilution on Off-Gas Composition (40 scfm minimum purge rate).

\begin{tabular}{|c|c|c|c|c|c|c|c|c|c|c|}
\hline $\begin{array}{l}\text { Peak Off-gas Rate } \\
\operatorname{scfm}^{\text {a }}\end{array}$ & $\begin{array}{c}\mathrm{H}_{2} \\
\mathrm{scfm}^{\mathrm{a}} \\
\end{array}$ & $\begin{array}{c}\mathrm{NO} \\
\text { scfm }^{\mathrm{a}} \\
\end{array}$ & $\begin{array}{c}\mathrm{N}_{2} \mathrm{O} \\
\text { scfm }^{\text {a }} \\
\end{array}$ & $\begin{array}{c}\mathrm{H}_{2} \\
\text { Diluted } \\
\end{array}$ & $\begin{array}{c}\text { NO } \\
\text { Diluted } \\
\end{array}$ & $\begin{array}{c}\mathrm{N}_{2} \mathrm{O} \\
\text { Diluted } \\
\end{array}$ & $\begin{array}{c}\text { Air } \\
\text { Diluted } \\
\end{array}$ & $\begin{array}{c}\mathrm{LFL} \\
28^{\circ} \mathrm{C}^{\mathrm{b}} \\
\end{array}$ & $\begin{array}{l}60 \% \mathrm{LFL} \\
200{ }^{\circ} \mathrm{C}^{\mathrm{c}}\end{array}$ & $\begin{array}{c}\text { LFL } \\
\text { Margin }\end{array}$ \\
\hline 20 & 1.4 & 14.3 & 4.3 & $2.3 \%$ & $23.8 \%$ & $7.2 \%$ & $66.7 \%$ & $6.03 \%$ & $2.9 \%$ & $0.6 \%$ \\
\hline 30 & 2.1 & 21.4 & 6.5 & $3.0 \%$ & $30.6 \%$ & $9.3 \%$ & $57.1 \%$ & $6.58 \%$ & $3.2 \%$ & $0.2 \%$ \\
\hline 34.37 & 2.4 & 24.5 & 7.4 & $3.2 \%$ & $33.0 \%$ & $10.0 \%$ & $53.8 \%$ & $6.65 \%$ & $3.2 \%$ & $0.0001 \%$ \\
\hline 40 & 2.8 & 28.6 & 8.6 & $3.5 \%$ & $35.7 \%$ & $10.8 \%$ & $50.0 \%$ & $6.70 \%$ & $3.3 \%$ & $-0.2 \%$ \\
\hline 50 & 3.5 & 35.7 & 10.8 & $3.9 \%$ & $39.7 \%$ & $12.0 \%$ & $44.4 \%$ & $6.82 \%$ & $3.3 \%$ & $-0.6 \%$ \\
\hline 60 & 4.2 & 42.8 & 13.0 & $4.2 \%$ & $42.8 \%$ & $13.0 \%$ & $40.0 \%$ & $6.80 \%$ & $3.3 \%$ & $-0.9 \%$ \\
\hline 70 & 4.9 & 50.0 & 15.1 & $4.5 \%$ & $45.4 \%$ & $13.8 \%$ & $36.4 \%$ & $6.73 \%$ & $3.3 \%$ & $-1.2 \%$ \\
\hline 80 & 5.6 & 57.1 & 17.3 & $4.7 \%$ & $47.6 \%$ & $14.4 \%$ & $33.3 \%$ & $6.63 \%$ & $3.3 \%$ & $-1.4 \%$ \\
\hline 90 & 6.3 & 64.2 & 19.5 & $4.8 \%$ & $49.4 \%$ & $15.0 \%$ & $30.8 \%$ & $6.53 \%$ & $3.2 \%$ & $-1.7 \%$ \\
\hline 100 & 7.0 & 71.4 & 21.6 & $5.0 \%$ & $51.0 \%$ & $15.4 \%$ & $28.6 \%$ & $6.47 \%$ & $3.1 \%$ & $-1.9 \%$ \\
\hline 130 & 9.1 & 92.8 & 28.1 & $5.4 \%$ & $54.6 \%$ & $16.5 \%$ & $23.5 \%$ & $6.37 \%$ & $3.1 \%$ & $-2.3 \%$ \\
\hline 150 & 10.5 & 107.1 & 32.4 & $5.5 \%$ & $56.4 \%$ & $17.1 \%$ & $21.1 \%$ & $6.32 \%$ & $3.1 \%$ & $-2.5 \%$ \\
\hline 200 & 14.0 & 142.8 & 43.2 & $5.8 \%$ & $59.5 \%$ & $18.0 \%$ & $16.7 \%$ & $6.23 \%$ & $3.0 \%$ & $-2.8 \%$ \\
\hline
\end{tabular}

These values for the LFL are assumed to be applicable anywhere in the region of $\mathrm{NO} / \mathrm{N}_{2} \mathrm{O}$ molar ratio of 2 to 5. Keeping the peak off-gas flowrate below $34.37 \mathrm{scfm}$ will maintain conditions in the iodine reactor below $60 \%$ of the LFL for a credited purge rate of $40 \mathrm{scfm}$.

At higher purge rates the allowed peak off-gas rate that maintains the off-gas stream below $60 \%$ of the LFL increases. Using the same assumptions for off-gas composition and the new value for the purge rate, the dilution effect is calculated. The corresponding value of the LFL for the diluted mixture is calculated based on the diluted air concentration from Scott's data and the temperature correction of the LFL is then calculated. Table 5 shows the effect of purge rates from 40 to $60 \mathrm{scfm}$ on the allowed peak off-gas rate. For example, increasing the credited purge rate from 40 to $45 \mathrm{scfm}$ allows the peak off-gas rate to increase from 34.37 to $38.67 \mathrm{scfm}$ while maintaining the off-gas below the LFL in the iodine reactor. Tables 4 and 5 only depend on the peak off-gas rate, composition of the off-gas and the LFL data used (Table 1). 
SRNL-STI-2010-00205, Rev 0

Table 5. Effect of Purge Rate Dilution on Off-Gas Composition.

\begin{tabular}{|c|c|c|c|c|c|c|c|c|c|c|c|}
\hline $\begin{array}{l}\text { Purge Rate } \\
\operatorname{scfm}^{a}\end{array}$ & $\begin{array}{c}\text { Peak Off-gas Rate } \\
\operatorname{scfm}^{\mathrm{a}}\end{array}$ & $\begin{array}{c}\mathrm{H}_{2} \\
\operatorname{scfm}^{\text {a }} \\
\end{array}$ & $\begin{array}{c}\mathrm{NO} \\
\operatorname{scfm}^{\mathrm{a}}\end{array}$ & $\begin{array}{c}\mathrm{N}_{2} \mathrm{O} \\
\operatorname{scfm}^{a} \\
\end{array}$ & $\begin{array}{c}\mathrm{H}_{2} \\
\text { Diluted } \\
\end{array}$ & $\begin{array}{c}\text { NO } \\
\text { Diluted } \\
\end{array}$ & $\begin{array}{c}\mathrm{N}_{2} \mathrm{O} \\
\text { Diluted } \\
\end{array}$ & Air & $\begin{array}{l}\text { LFL } \\
\text { est }\end{array}$ & $200{ }^{\circ} \mathrm{C}^{\mathrm{c}}$ & \\
\hline 40 & 34.37 & 2.4 & 24.5 & 7.4 & $3.24 \%$ & $33.0 \%$ & $10.0 \%$ & $53.8 \%$ & $6.65 \%$ & $3.24 \%$ & $0.0000 \%$ \\
\hline 41 & 35.23 & 2.5 & 25.1 & 7.6 & $3.24 \%$ & $33.0 \%$ & $10.0 \%$ & $53.8 \%$ & $6.65 \%$ & $3.24 \%$ & $0.0000 \%$ \\
\hline 42 & 36.09 & 2.5 & 25.8 & 7.8 & $3.24 \%$ & $33.0 \%$ & $10.0 \%$ & $53.8 \%$ & $6.65 \%$ & $3.24 \%$ & $0.0000 \%$ \\
\hline 43 & 36.95 & 2.6 & 26.4 & 8.0 & $3.24 \%$ & $33.0 \%$ & $10.0 \%$ & $53.8 \%$ & $6.65 \%$ & $3.24 \%$ & $0.0000 \%$ \\
\hline 44 & 37.81 & 2.6 & 27.0 & 8.2 & $3.24 \%$ & $33.0 \%$ & $10.0 \%$ & $53.8 \%$ & $6.65 \%$ & $3.24 \%$ & $0.0000 \%$ \\
\hline 45 & 38.67 & 2.7 & 27.6 & 8.4 & $3.24 \%$ & $33.0 \%$ & $10.0 \%$ & $53.8 \%$ & $6.65 \%$ & $3.24 \%$ & $0.0000 \%$ \\
\hline 46 & 39.53 & 2.8 & 28.2 & 8.5 & $3.24 \%$ & $33.0 \%$ & $10.0 \%$ & $53.8 \%$ & $6.65 \%$ & $3.24 \%$ & $0.0000 \%$ \\
\hline 47 & 40.39 & 2.8 & 28.8 & 8.7 & $3.24 \%$ & $33.0 \%$ & $10.0 \%$ & $53.8 \%$ & $6.65 \%$ & $3.24 \%$ & $0.0000 \%$ \\
\hline 48 & 41.25 & 2.9 & 29.4 & 8.9 & $3.24 \%$ & $33.0 \%$ & $10.0 \%$ & $53.8 \%$ & $6.65 \%$ & $3.24 \%$ & $0.0000 \%$ \\
\hline 49 & 42.11 & 2.9 & 30.1 & 9.1 & $3.24 \%$ & $33.0 \%$ & $10.0 \%$ & $53.8 \%$ & $6.65 \%$ & $3.24 \%$ & $0.0000 \%$ \\
\hline 50 & 42.96 & 3.0 & 30.7 & 9.3 & $3.24 \%$ & $33.0 \%$ & $10.0 \%$ & $53.8 \%$ & $6.65 \%$ & $3.24 \%$ & $0.0000 \%$ \\
\hline 52 & 44.68 & 3.1 & 31.9 & 9.7 & $3.24 \%$ & $33.0 \%$ & $10.0 \%$ & $53.8 \%$ & $6.65 \%$ & $3.24 \%$ & $0.0000 \%$ \\
\hline 55 & 47.26 & 3.3 & 33.7 & 10.2 & $3.24 \%$ & $33.0 \%$ & $10.0 \%$ & $53.8 \%$ & $6.65 \%$ & $3.24 \%$ & $0.0000 \%$ \\
\hline 60 & 51.56 & 3.6 & 36.8 & 11.1 & $3.24 \%$ & $33.0 \%$ & $10.0 \%$ & $53.8 \%$ & $6.65 \%$ & $3.24 \%$ & $0.0000 \%$ \\
\hline
\end{tabular}

Number of Fuel Bundles in the Initial Charge to the Dissolver:

The number of fuel bundles that can be charged to the dissolver in the initial charge will be limited based on flammability. The peak areal off-gas rate as determined by Kyser ${ }^{1}$ from the Carraciolo pilot scale data ${ }^{3}$ will be used $\left(1.351 \mathrm{scfm}\left(60^{\circ} \mathrm{F}, 1 \mathrm{~atm}\right) / \mathrm{ft}^{2}\right.$ outer area at $0.002 \mathrm{M}$ catalyst). A constant submergence of 54 in. of bundle will be assumed for all calculations. The combination of the outer surface areas as calculated by Laurinat ${ }^{9}$ with the submergence provides the exposed area for the calculation of the peak off-gas rate based on the number of fuel bundles charged to the dissolver in the initial charge. Note that this calculation continues to assume that the bounding off-gas rate is determined by the outer surface of the fuel bundle as discussed in the previous report ${ }^{1}$.

Table 6 shows the results of the calculation for the outer areas of both the MURR fuel assembly and the fuel bundle for a five bundle initial charge. Table 7 shows the results of this calculation for the outer bundle area as the number of bundles is increased from four to ten bundles. These peak off-gas results are calculated by the same methodology established in the previous report ${ }^{1}$. Calculations of the results shown in Tables 6 and 7 depend on the design of the fuel bundle (outer area), the catalyst and acid concentrations, and the peak areal off-gas rate (determined by Kyser ${ }^{1}$ from Carraciolo's data ${ }^{3}$ ).

Table 6. Calculated Areas and Peak Off-gas rates for an Initial Dissolver Charge of Five Bundles.

\begin{tabular}{lccc}
\hline & $\begin{array}{c}\text { Area } \\
\mathrm{ft}^{2} / \mathrm{ft}\end{array}$ & $\begin{array}{c}\text { Area } \\
\mathrm{ft}^{2}\end{array}$ & $\begin{array}{c}\text { Peak Off-gas } \\
\mathrm{scfm}^{\mathrm{b}}\end{array}$ \\
\hline MURR outer & 1.159 & 26.1 & $17.62^{\mathrm{c}}$ \\
Bundle outer & 1.269 & 28.6 & 38.58 \\
\hline${ }^{\mathrm{a}}$ Outer surface area per length of submerged section. \\
${ }^{\mathrm{b}}$ Peak off-gas rate of 1.351 cfm/ $\mathrm{ft}^{2}$ at $[\mathrm{Hg}]=0.002 \mathrm{M}$ from Kyser ${ }^{1}$. \\
${ }^{\mathrm{c}}$ Effect of irradiation on MURR material assumed to be $50 \%$ of unirradi- \\
ated aluminum.
\end{tabular}

Table 7. Calculated Outer Bundle Areas and Peak Off-gas Rates for an Initial Dissolver Charge.

\begin{tabular}{ccc}
\hline Bundles & $\begin{array}{c}\text { Area } \\
\mathrm{ft}^{2}\end{array}$ & $\begin{array}{c}\text { Peak Off-gas } \\
\text { scfm }^{\text {a }}\end{array}$ \\
\hline 4 & 22.8 & 30.87 \\
5 & 28.6 & 38.58 \\
6 & 34.3 & 46.30 \\
7 & 40.0 & 54.02 \\
8 & 45.7 & 61.73 \\
9 & 51.4 & 69.45 \\
10 & 57.1 & 77.17 \\
\hline${ }^{\mathrm{a}}$ Peak off-gas rate of $1.351 \mathrm{cfm} / \mathrm{ft}^{2}$ at \\
{$\left[\right.$ Hg] $=0.002$ M from Kyser ${ }^{1}$}
\end{tabular}




\section{Number of Fuel Bundles in the Second Charge to the Dissolver:}

For efficient operation and waste minimization reasons it is desirable to charge the dissolver batch with sufficient acid and fuel to result in dissolver product with acceptable fissile concentration in a final solution of $\sim 1.5 \mathrm{M}$ aluminum nitrate and $0.5 \mathrm{M}$ nitric acid concentrations. With bundles of MURR fuel, sufficient fuel cannot be added in a single charge to attain those conditions and multiple charges will be desirable for each dissolver batch. When multiple charges are performed, the presence of the catalyst from the initial charge causes additional reactivity (off-gas) during the heating cycle for the second charge as compared to that of the initial charge (when catalyst was not present). Dissolved aluminum counterbalances that effect by limiting the dissolution rate. The effect of dissolved aluminum on the dissolution rate is shown in Figures 3 and $4^{1,3,10}$. A regression of the $16 \mathrm{wt}$ $\%$ fuel data shown in Figure 4 (most similar to MURR fuel assemblies) yields equation 1. The reduc-

(1) Dissolution Rate $\left(\mathrm{mg} / \mathrm{min} / \mathrm{cm}^{2}\right)=102.64 * 10^{-1.078 *[\mathrm{Al}]}$, (for $16 \mathrm{wt} \% \mathrm{U}-\mathrm{Al}$, Al clad tubular fuel, $\left.[\mathrm{Hg}]=0.001\right)$

$$
\left.=52.53 \mathrm{mg} / \mathrm{min} / \mathrm{cm}^{2} \text {, (at } 0.27 \mathrm{M} \mathrm{Al}\right)
$$

(2) Effect of $\mathrm{Al}$ on Dissolution rate $=\left(102.64 * 10^{-1.078 *[\mathrm{Al}]}\right) / 52.53=102.64 / 52.53 * 10^{-1.078 *[\mathrm{Al}]}$

Since it is a ratio referenced to $0.27 \mathrm{M} \mathrm{Al}$, equation 2 is independent of $[\mathrm{Hg}]$.

$\mathrm{Q} / \mathrm{A}=1.351 \mathrm{scfm}\left(60^{\circ} \mathrm{F}, 1 \mathrm{~atm}\right) / \mathrm{ft}^{2} @ 0.002 \mathrm{M} \mathrm{Hg} \quad$ (from Carraciolo's data (Ref. 1))

$\mathrm{Q}_{\text {limit }}=$ Peak Off-gas Rate (from Table 5), determined from LFL data and credited purge rate, $=38.67 \mathrm{scfm}$ for $45 \mathrm{scfm}$ purge (from Table 5)

Area $=5.710 \mathrm{ft}^{2} /$ bundle for $54 \mathrm{in}$. submergence, $\left(1.269 \mathrm{ft}^{2} / \mathrm{ft}^{*} * 54 \mathrm{in} / 12 \mathrm{in} / \mathrm{ft}\right)$

(3) $\mathrm{Q}_{\text {limit }}=1.351 \mathrm{scfm} / \mathrm{ft}^{2} *$ Area $* \mathrm{~N}$ bundles $*[\mathrm{Hg}] / 0.002 *(102.64 / 52.53) * 10^{-1.078 *[\mathrm{Al}]}$

Solve for $[\mathrm{Al}]$ :

(4) $[\mathrm{Al}]_{\min }=(1 / 1.078) * \log _{10}\left\{\left(1.351 \mathrm{scfm} / \mathrm{ft}^{2}\right) / \mathrm{Q}_{\text {limit }} *\right.$ Area $* \mathrm{~N}$ bundles $\left.*[\mathrm{Hg}] / 0.002 *(102.64 / 52.53)\right\}$ see appendix for additional detail (pg 21).

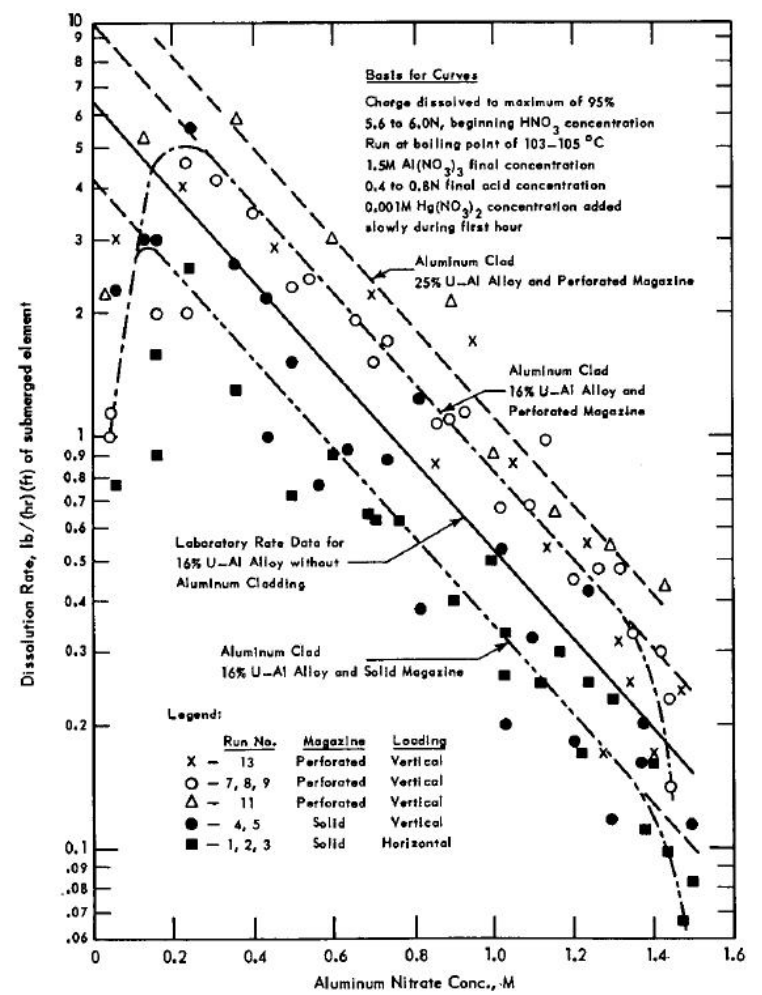

Figure 3. Effect of Aluminum Nitrate Concentration on the Dissolution Rate Characteristics of Fuel Elements (Aluminum - 16 wt \% Uranium Alloy) ${ }^{3}$.

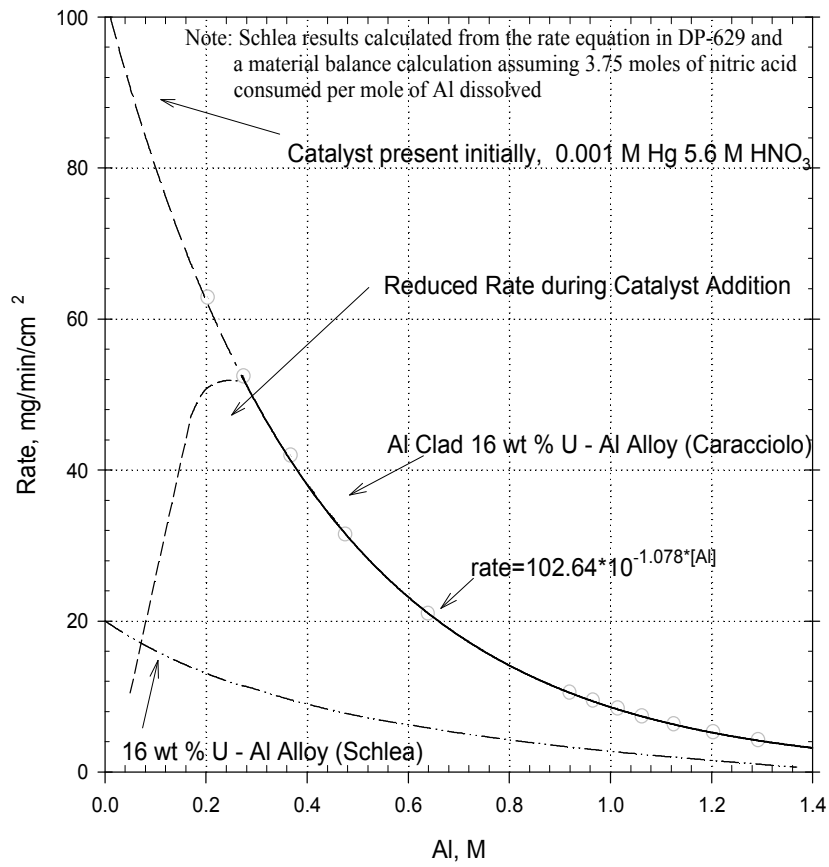

Note: Rate at end of catalyst addition $(\sim 0.27 \mathrm{M} \mathrm{Al})=52.53 \mathrm{mg} / \mathrm{min} / \mathrm{cm}^{2}$

Figure 4. Effect of Aluminum Dissolution and Nitric Acid Consumption on the Dissolution Rate ${ }^{1,3,10}$. 
tion in the dissolution rate in successive charges by dissolved aluminum (as compared to the rate in an initial charge) is represented by equation 2 . Several key assumptions were made: 1) the off-gas rate scales with the dissolution rate 2 ) the peak off-gas rate observed by Carraciolo ${ }^{1,3}$ corresponded to the completion of the catalyst addition, 3 ) the rate (off-gas or dissolution) is proportional to the exposed surface area of the fuel bundles and 4) the rate is proportional to the catalyst concentration. With these assumptions, equation 2, combined with peak off-gas measurements and allowable off-gas rates, was rearranged to solve for minimum aluminum concentration, (equation 4) which will limit the dis-

Table 8. Effect of Catalyst and Aluminum Concentration on the Size of a Fuel Charge for Various Purge Rates.

\begin{tabular}{|c|c|c|c|c|c|}
\hline \multirow{2}{*}{\multicolumn{2}{|c|}{$\begin{array}{l}\text { Purge Rate, cfm } \\
\text { Peak Off-gas rate, cfm }\end{array}$}} & 40 & 45 & 50 & 55 \\
\hline & & 34.37 & 38.67 & 42.96 & 47.26 \\
\hline \multirow{3}{*}{$\begin{array}{c}\text { Total } \\
{[\mathrm{Hg}], \mathrm{M}} \\
\end{array}$} & \multicolumn{5}{|l|}{ Allowed } \\
\hline & \multirow{2}{*}{$\begin{array}{c}\text { Bundles } \\
\text { Next Chrg }\end{array}$} & \multicolumn{4}{|c|}{ Min. Required $\mathrm{Al}^{\mathrm{a}}$} \\
\hline & & $\mathrm{M}$ & $\mathrm{M}$ & $\mathrm{M}$ & $\mathrm{M}$ \\
\hline 0.002 & 1 & 0 & 0 & 0 & 0 \\
\hline 0.002 & 2 & 0 & 0 & 0 & 0 \\
\hline 0.002 & 3 & 0.111 & 0.063 & 0.021 & 0 \\
\hline 0.002 & 4 & 0.227 & 0.179 & 0.137 & 0.098 \\
\hline 0.002 & 5 & 0.316 & 0.269 & 0.227 & 0.188 \\
\hline 0.002 & 6 & 0.390 & 0.342 & 0.300 & 0.262 \\
\hline 0.002 & 7 & 0.452 & 0.405 & 0.362 & 0.324 \\
\hline 0.002 & 8 & 0.506 & 0.458 & 0.416 & 0.377 \\
\hline 0.002 & 9 & 0.553 & 0.506 & 0.463 & 0.425 \\
\hline 0.002 & 10 & 0.596 & 0.548 & 0.506 & 0.467 \\
\hline 0.003 & 1 & 0 & 0 & 0 & 0 \\
\hline 0.003 & 2 & 0.111 & 0.063 & 0.021 & 0 \\
\hline 0.003 & 3 & 0.274 & 0.227 & 0.184 & 0.146 \\
\hline 0.003 & 4 & 0.390 & 0.342 & 0.300 & 0.262 \\
\hline 0.003 & 5 & 0.480 & 0.432 & 0.390 & 0.351 \\
\hline 0.003 & 6 & 0.553 & 0.506 & 0.463 & 0.425 \\
\hline 0.003 & 7 & 0.615 & 0.568 & 0.525 & 0.487 \\
\hline 0.003 & 8 & 0.669 & 0.622 & 0.579 & 0.541 \\
\hline 0.003 & 9 & 0.717 & 0.669 & 0.627 & 0.588 \\
\hline 0.003 & 10 & 0.759 & 0.712 & 0.669 & 0.631 \\
\hline 0.004 & 1 & 0 & 0 & 0 & 0 \\
\hline 0.004 & 2 & 0.227 & 0.179 & 0.137 & 0.098 \\
\hline 0.004 & 3 & 0.390 & 0.342 & 0.300 & 0.262 \\
\hline 0.004 & 4 & 0.506 & 0.458 & 0.416 & 0.377 \\
\hline 0.004 & 5 & 0.596 & 0.548 & 0.506 & 0.467 \\
\hline 0.004 & 6 & 0.669 & 0.622 & 0.579 & 0.541 \\
\hline 0.004 & 7 & 0.731 & 0.684 & 0.641 & 0.603 \\
\hline 0.004 & 8 & 0.785 & 0.738 & 0.695 & 0.657 \\
\hline 0.004 & 9 & 0.832 & 0.785 & 0.743 & 0.704 \\
\hline 0.004 & 10 & 0.875 & 0.827 & 0.785 & 0.747 \\
\hline
\end{tabular}

${ }^{a}$ Min. [Al] required to meet $60 \mathrm{vol} \% \mathrm{LFL}$ standard at $200{ }^{\circ} \mathrm{C}$ for calculated peak off-gas rate.

Assumptions:

1. Peak off-gas rate of $1.351 \mathrm{scfm}\left(60^{\circ} \mathrm{F}, 1 \mathrm{~atm}\right.$. $) / \mathrm{ft}^{2}$ at $[\mathrm{Hg}]=0.002 \mathrm{M}^{1}$.

2. Fuel submergence equal to 54 in. which results in $5.710 \mathrm{ft}^{2} /$ bundle outer area.

3. $[\mathrm{Hg}]$ assumed present prior to introduction of fuel to dissolver. solution rate to control the off-gas to the LFL limit for successive charges with aluminum and catalyst in the dissolver solution.

The dissolution rate (and peak off-gas rate) is therefore controlled by the aluminum and nitric acid concentrations in the dissolver at the initiation of the second charge (at this point we have not discussed a second catalyst addition). These concentrations are primarily determined by the solution volume in the dissolver, the initial nitric acid concentration and the number of bundles of fuel in the initial charge. The number of bundles in the initial charge can be used with Tables 2 or 3 to determine the expected aluminum concentration at the start of the second charge (MURR fuel only). Thus for a given credited purge rate (which determines the allowable peak off-gas rate), the number of bundles that can be included in a second charge to the same dissolver batch can be determined based on the amount of soluble aluminum present via equation 4 . The initial section of Table 8 shows the results of these calculations for a credited purge rate from 40 to $55 \mathrm{cfm}$ for a catalyst concentration of $0.002 \mathrm{M} \mathrm{Hg}$. Note that Table 8 depends on the purge rate and the aluminum and catalyst concentrations (not the dissolver solution volume). Tables 2 and 3 (which depend on the number of bundles charged and dissolver solution volume) can be used to determine the aluminum concentration. Tables 2 and 3 are specific to MURR fuel due to credit taken for the specific aluminum and uranium contents of that type of fuel bundle assuming that each bundle contains four assemblies. 


\section{Effect of Increasing the Catalyst Concentration on a Subsequent Charge:}

The presence of dissolved aluminum (and depletion of nitric acid) reduces the rate of dissolution and this effect has been credited in the calculation of the amount of fuel that may be charged in a second charge. At some point the aluminum concentration will reduce the dissolution rate such that a second catalyst addition may be desirable to reduce the cycle time. Equation 4 includes the effect of increased catalyst concentration in the calculation of the minimum aluminum concentration to control the peak off-gas rate to the bounding value observed in the Carraciolo work ${ }^{1,3}$. As before, this calculation depends on the purge rate, aluminum concentration, along with the catalyst concentration. Table 8 shows the minimum aluminum concentration (calculated from equation 4) required to control the peak off-gas rate to the bounding values for catalyst concentrations of $0.002 \mathrm{M}$ (baseline), 0.003 $\mathrm{M}$ and $0.004 \mathrm{M}$ total mercuric nitrate. Note that Table 8 assumes that the catalyst is present prior to the introduction of the fuel charge although additional catalyst should be metered into the boiling dissolver solution in the same manner as the initial catalyst addition to aid in the control of the reaction. The assumption that the catalyst is already present conservatively controls the off-gas rate but provides minimal limits on the conditions where additional catalyst might be used.

The number of bundles that can be charged in subsequent charges (third, fourth, etc.) to the dissolvers would also be dependent on the purge rate and aluminum and catalyst concentrations as outlined above.

\section{CONCLUSIONS}

This report provides updated values for the lower flammability limit of the expected off-gas from the dissolution of aluminum clad uranium-aluminum alloy fuels. It follows the protocol as established in the previous report on MURR fuels and extends the calculations from 40 to $55 \mathrm{scfm}$ purge and from 12000 to 15000 liters of dissolver solution volume. Additional values are also provided for the 6000 to 7500 liter volume range for the smaller H-Canyon dissolver. Catalyst concentrations of 0.002 to $0.004 \mathrm{M}$ mercuric nitrate were considered on subsequent fuel charges to be utilized as needed to safely shorten the dissolution time. The tabular results provide the basis to determine limitations on both the initial and successive charges for a range of purge rates, solution volumes and catalyst concentrations for MURR bundled fuel. Other fuel types will require generation of additional tables to take into account the differing aluminum and uranium contents of those fuels.

\section{ACKNOWLEDGEMENTS}

The author wishes to acknowledge the assistance of a range of individuals who provided assistance during this extension of the previous work. This work benefited from extensive discussions with or assistance provided by John Scogin, Neal Askew, James Laurinat and Bill Clifton.

\section{REFERENCES}

${ }^{1}$ E. A. Kyser, "Dissolution of Irradiated MURR Fuel Assemblies", SRNL-STI-2010-00005, Rev 2, Savannah River National Laboratory, Aiken, SC, June 17, 2010.

${ }^{2}$ W. H. Clifton, "Flowsheet Evaluation for Dissolution of Spent Nuclear Fuel", NMD-HTS-2010-3140, Technical Task Request, Savannah River Nuclear Solutions, Aiken, SC, March 9, 2010.

${ }^{3}$ V. P. Caracciolo, "Dissolver for Uranium-Aluminum Alloy Tubes", DP-398, E. I. du Pont de Nemours and Company, Savannah River Laboratory, Aiken, SC, September 1959.

${ }^{4}$ F. R. Weitz, "H-Canyon Dissolver Hydrogen Dilution Calculations using Off-Gas Specific Lower Flammability Limit (LFL)", X-CLC-H-00473, Westinghouse Savannah River Company, Aiken, SC, October 2, 2003.

${ }^{5}$ F. E. Scott, M. G. Zabetakis, "Flammability of Hydrogen-Air-Nitrogen Oxide Mixtures", AECU-3178 or BM3507, United States Department of the Interior; Bureau of Mines, Pittsburg, PA, 1956.

${ }^{6}$ W. G. Dyer, J. C. Williams, "Impact of Temperature on Hydrogen Lower Flammability Limit for Separations Facilities", WSRC-TR-2003-00313, Rev 0, Westinghouse Savannah River Company, Aiken, SC, July 2003. 
${ }^{7}$ M. Hertzberg, K.L. Cashdollar, "Flammability Behavior and Pressure Development of Hydrogen Mixtures in containment volumes", Vol. 1, Thermal-Hydraulics of Nuclear Reactors, The Second International topical Meeting on Nuclear Reactor Thermal-Hydraulics held at Santa Barbara, CA January 11-14 1983, American Nuclear Society, LaGrange Park, IL, 1983.

${ }^{8}$ G. Ciccarelli, D. Jackson, J. Verreault, "Flammability Limits of $\mathrm{NH}_{3}-\mathrm{H}_{2}-\mathrm{N}_{2}$-Air Mixtures at Elevated Initial Temperatures", Combustion and Flame, 2006, Vol. 144, pp 53-63.

9 J. E. Laurinat, "Calculation of Surface Area for Dissolution of MURR Fuel", X-CLC-H-00800, Rev 0, Savannah River National Laboratory, Aiken, SC, December 17, 2009.

${ }^{10}$ C. S. Schlea, "The Dissolution of Uranium-Aluminum Alloy", DP-629, E. I. du Pont de Nemours and Company, Savannah River Laboratory, Aiken, SC, September 1961. 
APPENDIX 
Table 9. Effect of the Number of MURR Bundles Charged on the Aluminum and Uranium Concentration (14000 L solution volume).

\begin{tabular}{|c|c|c|c|c|c|c|c|}
\hline $\begin{array}{c}\text { Vol } \\
\text { L }\end{array}$ & Bundles & $\begin{array}{c}\mathrm{Al} \\
\mathrm{kg}^{\mathrm{a}}\end{array}$ & $\begin{array}{c}\mathrm{U} \\
\mathrm{kg}\end{array}$ & $\begin{array}{l}\mathrm{Al} \\
\mathrm{M}\end{array}$ & $\begin{array}{c}{ }^{235} \mathrm{U} \\
\mathrm{g} / \mathrm{L}\end{array}$ & $\begin{array}{l}{ }^{235} \mathrm{U} \\
\mathrm{g} / \mathrm{L}^{\mathrm{b}}\end{array}$ & $\begin{array}{c}\mathrm{HNO}_{3} \\
\mathrm{M}^{\mathrm{c}}\end{array}$ \\
\hline 14000 & 1 & 28.5 & 3.3 & 0.075 & 0.22 & 0.18 & 0.79 \\
\hline 14000 & 2 & 56.9 & 6.6 & 0.151 & 0.44 & 0.35 & 1.07 \\
\hline 14000 & 3 & 85.4 & 10.0 & 0.226 & 0.66 & 0.53 & 1.36 \\
\hline 14000 & 4 & 114 & 13.3 & 0.302 & 0.88 & 0.71 & 1.65 \\
\hline 14000 & 5 & 142 & 16.6 & 0.377 & 1.10 & 0.88 & 1.93 \\
\hline 14000 & 6 & 171 & 19.9 & 0.452 & 1.32 & 1.06 & 2.22 \\
\hline 14000 & 7 & 199 & 23.3 & 0.528 & 1.55 & 1.24 & 2.51 \\
\hline 14000 & 8 & 228 & 26.6 & 0.603 & 1.77 & 1.41 & 2.79 \\
\hline 14000 & 9 & 256 & 29.9 & 0.678 & 1.99 & 1.59 & 3.08 \\
\hline 14000 & 10 & 285 & 33.2 & 0.754 & 2.21 & 1.77 & 3.37 \\
\hline 14000 & 11 & 313 & 36.6 & 0.829 & 2.43 & 1.94 & 3.65 \\
\hline 14000 & 12 & 342 & 39.9 & 0.905 & 2.65 & 2.12 & 3.94 \\
\hline 14000 & 13 & 370 & 43.2 & 0.980 & 2.87 & 2.30 & 4.23 \\
\hline 14000 & 14 & 399 & 46.5 & 1.055 & 3.09 & 2.47 & 4.51 \\
\hline 14000 & 15 & 427 & 49.9 & 1.131 & 3.31 & 2.65 & 4.80 \\
\hline 14000 & 16 & 456 & 53.2 & 1.206 & 3.53 & 2.83 & 5.09 \\
\hline 14000 & 17 & 484 & 56.5 & 1.281 & 3.75 & 3.00 & 5.37 \\
\hline
\end{tabular}

a Assumes $6.8 \mathrm{~kg} \mathrm{Al} /$ bundle $+5.418 \mathrm{~kg} \mathrm{Al} /$ assembly, 4 assemblies/bundle .

${ }^{\mathrm{b}}$ Post irradiation values assuming $20 \%$ burn-up of ${ }^{235} \mathrm{U}$.

${ }^{\mathrm{c}}$ Initial acid required: $0.5 \mathrm{M}$ excess acid, 3.75 moles of acid consumed per mole of Al, 4 moles of acid consumed per mole of $\mathrm{U}$.

Table 10. Effect of the Number of MURR Bundles Charged on the Aluminum and Uranium Concentration (13000 L solution volume).

\begin{tabular}{cccccccc}
\hline $\begin{array}{c}\text { Vol } \\
\mathrm{L}\end{array}$ & Bundles & $\begin{array}{c}\mathrm{Al} \\
\mathrm{kg}\end{array}$ & $\begin{array}{c}\mathrm{U} \\
\mathrm{kg}\end{array}$ & $\begin{array}{c}\mathrm{Al} \\
\mathrm{M}\end{array}$ & $\begin{array}{c}{ }^{235} \mathrm{U} / \mathrm{L} \\
\mathrm{g} / \mathrm{L}^{\mathrm{b}}\end{array}$ & $\begin{array}{c}{ }^{235} \mathrm{MNO} \\
\mathrm{M}^{\mathrm{c}}\end{array}$ \\
\hline 13000 & 1 & 28.5 & 3.3 & 0.081 & 0.24 & 0.19 & 0.81 \\
13000 & 2 & 56.9 & 6.6 & 0.162 & 0.48 & 0.38 & 1.12 \\
13000 & 3 & 85.4 & 10.0 & 0.244 & 0.71 & 0.57 & 1.43 \\
13000 & 4 & 114 & 13.3 & 0.325 & 0.95 & 0.76 & 1.74 \\
13000 & 5 & 142 & 16.6 & 0.406 & 1.19 & 0.95 & 2.04 \\
13000 & 6 & 171 & 19.9 & 0.487 & 1.43 & 1.14 & 2.35 \\
13000 & 7 & 199 & 23.3 & 0.568 & 1.66 & 1.33 & 2.66 \\
13000 & 8 & 228 & 26.6 & 0.649 & 1.90 & 1.52 & 2.97 \\
13000 & 9 & 256 & 29.9 & 0.731 & 2.14 & 1.71 & 3.28 \\
13000 & 10 & 285 & 33.2 & 0.812 & 2.38 & 1.90 & 3.59 \\
13000 & 11 & 313 & 36.6 & 0.893 & 2.62 & 2.09 & 3.90 \\
13000 & 12 & 342 & 39.9 & 0.974 & 2.85 & 2.28 & 4.21 \\
13000 & 13 & 370 & 43.2 & 1.055 & 3.09 & 2.47 & 4.51 \\
13000 & 14 & 399 & 46.5 & 1.136 & 3.33 & 2.66 & 4.82 \\
13000 & 15 & 427 & 49.9 & 1.218 & 3.57 & 2.85 & 5.13 \\
13000 & 16 & 456 & 53.2 & 1.299 & 3.80 & 3.04 & 5.44 \\
13000 & 17 & 484 & 56.5 & 1.380 & 4.04 & 3.23 & 5.75 \\
\hline
\end{tabular}

${ }^{\mathrm{a}}$ Assumes $6.8 \mathrm{~kg} \mathrm{Al} / \mathrm{bundle}+5.418 \mathrm{~kg} \mathrm{Al} /$ assembly, 4 assemblies/bundle

${ }^{\mathrm{b}}$ Post irradiation values assuming $20 \%$ burn-up of ${ }^{235} \mathrm{U}$.

${ }^{\mathrm{c}}$ Initial acid required: $0.5 \mathrm{M}$ excess acid, 3.75 moles of acid consumed per mole of Al, 4 moles of acid consumed per mole of $\mathrm{U}$. 
Table 11. Effect of the Number of MURR Bundles Charged on the Aluminum and Uranium Concentration $(7500 \mathrm{~L}$ solution volume).

\begin{tabular}{cccccccc}
\hline $\begin{array}{c}\text { Vol } \\
\mathrm{L}\end{array}$ & Bundles & $\begin{array}{c}\mathrm{Al} \\
\mathrm{kg}\end{array}$ & $\begin{array}{c}\mathrm{U} \\
\mathrm{kg}\end{array}$ & $\begin{array}{c}\mathrm{Al} \\
\mathrm{M}\end{array}$ & $\begin{array}{c}{ }^{235} \mathrm{U} / \mathrm{L} \\
\mathrm{g}\end{array}$ & $\begin{array}{c}{ }^{235} \mathrm{U} / \mathrm{L} \\
\mathrm{b}\end{array}$ & $\begin{array}{c}\mathrm{HNO}_{3} \\
\mathrm{M}^{\mathrm{c}}\end{array}$ \\
\hline 7500 & 1 & 28.5 & 3.3 & 0.141 & 0.41 & 0.33 & 1.04 \\
7500 & 2 & 56.9 & 6.6 & 0.281 & 0.82 & 0.66 & 1.57 \\
7500 & 3 & 85.4 & 10.0 & 0.422 & 1.24 & 0.99 & 2.11 \\
7500 & 4 & 114 & 13.3 & 0.563 & 1.65 & 1.32 & 2.64 \\
7500 & 5 & 142 & 16.6 & 0.704 & 2.06 & 1.65 & 3.18 \\
7500 & 6 & 171 & 19.9 & 0.844 & 2.47 & 1.98 & 3.71 \\
7500 & 7 & 199 & 23.3 & 0.985 & 2.89 & 2.31 & 4.25 \\
7500 & 8 & 228 & 26.6 & 1.126 & 3.30 & 2.64 & 4.78 \\
7500 & 9 & 256 & 29.9 & 1.266 & 3.71 & 2.97 & 5.32 \\
7500 & 10 & 285 & 33.2 & 1.407 & 4.12 & 3.30 & 5.85 \\
7500 & 11 & 313 & 36.6 & 1.548 & 4.53 & 3.63 & 6.39 \\
\hline
\end{tabular}

${ }^{\mathrm{a}}$ Assumes $6.8 \mathrm{~kg} \mathrm{Al} / \mathrm{bundle}+5.418 \mathrm{~kg} \mathrm{Al} /$ assembly, 4 assemblies/bundle.

${ }^{\mathrm{b}}$ Post irradiation values assuming $20 \%$ burn-up of ${ }^{235} \mathrm{U}$.

${ }^{\mathrm{c}}$ Initial acid required: $0.5 \mathrm{M}$ excess acid, 3.75 moles of acid consumed per mole of Al, 4 moles of acid consumed per mole of $U$.

Table 12. Effect of the Number of MURR Bundles Charged on the Aluminum and Uranium Concentration (7000 L solution volume).

\begin{tabular}{|c|c|c|c|c|c|c|c|}
\hline $\begin{array}{c}\text { Vol } \\
\text { L }\end{array}$ & Bundles & $\begin{array}{c}\mathrm{Al} \\
\mathrm{kg}^{\mathrm{a}}\end{array}$ & $\begin{array}{c}\mathrm{U} \\
\mathrm{kg}\end{array}$ & $\begin{array}{l}\mathrm{Al} \\
\mathrm{M}\end{array}$ & $\begin{array}{l}{ }^{235} \mathrm{U} \\
\mathrm{g} / \mathrm{L}\end{array}$ & $\begin{array}{l}{ }^{235} \mathrm{U} \\
\mathrm{g} / \mathrm{L}^{\mathrm{b}}\end{array}$ & $\begin{array}{c}\mathrm{HNO}_{3} \\
\mathrm{M}^{\mathrm{c}} \\
\end{array}$ \\
\hline 7000 & 1 & 28.5 & 3.3 & 0.151 & 0.44 & 0.35 & 1.07 \\
\hline 7000 & 2 & 56.9 & 6.6 & 0.302 & 0.88 & 0.71 & 1.65 \\
\hline 7000 & 3 & 85.4 & 10.0 & 0.452 & 1.32 & 1.06 & 2.22 \\
\hline 7000 & 4 & 114 & 13.3 & 0.603 & 1.77 & 1.41 & 2.79 \\
\hline 7000 & 5 & 142 & 16.6 & 0.754 & 2.21 & 1.77 & 3.37 \\
\hline 7000 & 6 & 171 & 19.9 & 0.905 & 2.65 & 2.12 & 3.94 \\
\hline 7000 & 7 & 199 & 23.3 & 1.055 & 3.09 & 2.47 & 4.51 \\
\hline 7000 & 8 & 228 & 26.6 & 1.206 & 3.53 & 2.83 & 5.09 \\
\hline 7000 & 9 & 256 & 29.9 & 1.357 & 3.97 & 3.18 & 5.66 \\
\hline 7000 & 10 & 285 & 33.2 & 1.508 & 4.42 & 3.53 & 6.23 \\
\hline
\end{tabular}

${ }^{\mathrm{a}}$ Assumes $6.8 \mathrm{~kg} \mathrm{Al} /$ bundle $+5.418 \mathrm{~kg} \mathrm{Al} /$ assembly, 4 assemblies/bundle.

${ }^{\mathrm{b}}$ Post irradiation values assuming $20 \%$ burn-up of ${ }^{235} \mathrm{U}$.

${ }^{\mathrm{c}}$ Initial acid required: $0.5 \mathrm{M}$ excess acid, 3.75 moles of acid consumed per mole of Al, 4 moles of acid consumed per mole of $U$. 
Table 13. Effect of the Number of MURR Bundles Charged on the Aluminum and Uranium Concentration (6500 L solution volume).

\begin{tabular}{cccccccc}
\hline $\begin{array}{c}\text { Vol } \\
\mathrm{L}\end{array}$ & Bundles & $\begin{array}{c}\mathrm{Al} \\
\mathrm{kg}\end{array}$ & $\begin{array}{c}\mathrm{U} \\
\mathrm{kg}\end{array}$ & $\begin{array}{c}\mathrm{Al} \\
\mathrm{M}\end{array}$ & $\begin{array}{c}{ }^{235} \mathrm{U} / \mathrm{L} \\
\mathrm{g} / \mathrm{L}^{\mathrm{b}}\end{array}$ & $\begin{array}{c}\mathrm{HNO}_{3} \\
\mathrm{M}^{\mathrm{c}}\end{array}$ \\
\hline 6500 & 1 & 28.5 & 3.3 & 0.162 & 0.48 & 0.38 & 1.12 \\
6500 & 2 & 56.9 & 6.6 & 0.325 & 0.95 & 0.76 & 1.74 \\
6500 & 3 & 85.4 & 10.0 & 0.487 & 1.43 & 1.14 & 2.35 \\
6500 & 4 & 114 & 13.3 & 0.649 & 1.90 & 1.52 & 2.97 \\
6500 & 5 & 142 & 16.6 & 0.812 & 2.38 & 1.90 & 3.59 \\
6500 & 6 & 171 & 19.9 & 0.974 & 2.85 & 2.28 & 4.21 \\
6500 & 7 & 199 & 23.3 & 1.136 & 3.33 & 2.66 & 4.82 \\
6500 & 8 & 228 & 26.6 & 1.299 & 3.80 & 3.04 & 5.44 \\
6500 & 9 & 256 & 29.9 & 1.461 & 4.28 & 3.42 & 6.06 \\
6500 & 10 & 285 & 33.2 & 1.624 & 4.76 & 3.80 & 6.68 \\
\hline
\end{tabular}

${ }^{\mathrm{a}}$ Assumes $6.8 \mathrm{~kg} \mathrm{Al} / \mathrm{bundle}+5.418 \mathrm{~kg} \mathrm{Al} /$ assembly, 4 assemblies/bundle.

${ }^{\mathrm{b}}$ Post irradiation values assuming $20 \%$ burn-up of ${ }^{235} \mathrm{U}$.

${ }^{\mathrm{c}}$ Initial acid required: $0.5 \mathrm{M}$ excess acid, 3.75 moles of acid consumed per mole of Al, 4 moles of acid consumed per mole of $\mathrm{U}$.

Table 14. Effect of the Number of MURR Bundles Charged on the Aluminum and Uranium Concentration (6000 L solution volume).

\begin{tabular}{cccccccc}
\hline $\begin{array}{c}\text { Vol } \\
\mathrm{L}\end{array}$ & Bundles & $\begin{array}{c}\mathrm{Al} \\
\mathrm{kg}\end{array}$ & $\begin{array}{c}\mathrm{U} \\
\mathrm{kg}\end{array}$ & $\begin{array}{c}\mathrm{Al} \\
\mathrm{M}\end{array}$ & $\begin{array}{c}{ }^{235} \mathrm{U} / \mathrm{L} \\
{ }^{235} \mathrm{U} / \mathrm{L}^{\mathrm{b}}\end{array}$ & $\begin{array}{c}\mathrm{HNO}_{3} \\
\mathrm{M}^{\mathrm{c}}\end{array}$ \\
\hline 6000 & 1 & 28.5 & 3.3 & 0.176 & 0.52 & 0.41 & 1.17 \\
6000 & 2 & 56.9 & 6.6 & 0.352 & 1.03 & 0.82 & 1.84 \\
6000 & 3 & 85.4 & 10.0 & 0.528 & 1.55 & 1.24 & 2.51 \\
6000 & 4 & 114 & 13.3 & 0.704 & 2.06 & 1.65 & 3.18 \\
6000 & 5 & 142 & 16.6 & 0.879 & 2.58 & 2.06 & 3.84 \\
6000 & 6 & 171 & 19.9 & 1.055 & 3.09 & 2.47 & 4.51 \\
6000 & 7 & 199 & 23.3 & 1.231 & 3.61 & 2.89 & 5.18 \\
6000 & 8 & 228 & 26.6 & 1.407 & 4.12 & 3.30 & 5.85 \\
6000 & 9 & 256 & 29.9 & 1.583 & 4.64 & 3.71 & 6.52 \\
6000 & 10 & 285 & 33.2 & 1.759 & 5.15 & 4.12 & 7.19 \\
\hline
\end{tabular}

${ }^{\mathrm{a}}$ Assumes $6.8 \mathrm{~kg} \mathrm{Al} / \mathrm{bundle}+5.418 \mathrm{~kg} \mathrm{Al} /$ assembly, 4 assemblies/bundle.

${ }^{\mathrm{b}}$ Post irradiation values assuming $20 \%$ burn-up of ${ }^{235} \mathrm{U}$.

${ }^{\mathrm{c}}$ Initial acid required: $0.5 \mathrm{M}$ excess acid, 3.75 moles of acid consumed per mole of Al, 4 moles of acid consumed per mole of $\mathrm{U}$. 
Derivation of the equations describing the effect of $\mathrm{Al}$ and catalyst concentrations on a subsequent charge. (pg 13 this report)

(1) Dissolution Rate $\left(\mathrm{mg} / \mathrm{min} / \mathrm{cm}^{2}\right)=102.64 * 10^{-1.078 *}[\mathrm{Al}]$, (for $16 \mathrm{wt} \% \mathrm{U}-\mathrm{Al}$, Al clad tubular fuel, $\left.[\mathrm{Hg}]=0.001\right)$ $=52.53 \mathrm{mg} / \mathrm{min} / \mathrm{cm}^{2}$, (at $0.27 \mathrm{M} \mathrm{Al}$ )

(2) Effect of $\mathrm{Al}$ on Dissolution $\left.=\left(102.64 * 10^{-1.078 *[\mathrm{Al}]}\right) / 52.53=(102.64 / 52.53) 10^{-1.078 *[\mathrm{Al}]}\right)$, for $[\mathrm{Al}]>0.27 \mathrm{M}$ Referenced to end of catalyst addition at $0.27 \mathrm{M} \mathrm{Al}$.

Since it is a ratio referenced to $0.27 \mathrm{M} \mathrm{Al}$, equation 2 is independent of $[\mathrm{Hg}]$.

Assume off-gas rate directly proportional to dissolution rate and the observed peak off-gas rate corresponds to the dissolution rate at the end of catalyst addition, $(0.27 \mathrm{M} \mathrm{Al})$

$\mathrm{Q} / \mathrm{A}=1.351 \mathrm{scfm}\left(60^{\circ} \mathrm{F}, 1 \mathrm{~atm}\right) / \mathrm{ft}^{2} @ 0.002 \mathrm{M} \mathrm{Hg}$, (from Carraciolo's data (Ref. 1)

Area $(\mathrm{A})=5.710 \mathrm{ft}^{2} /$ bundle for $54 \mathrm{in}$. submergence, $\left(1.269 \mathrm{ft}^{2} / \mathrm{ft} * 54 \mathrm{in} / 12 \mathrm{in} / \mathrm{ft}\right)$

Adding in effect of $\mathrm{N}$ bundles charged, [Hg], [Al]

(3) $\mathrm{Q}=1.351 \mathrm{scfm} / \mathrm{ft}^{2} *$ Area $* \mathrm{~N}$ bundles $*[\mathrm{Hg}] / 0.002 *(102.64 / 52.53) * 10^{-1.078 *[\mathrm{Al}]}$

$\mathrm{Q}_{\text {limit }}=$ Peak Off-gas Rate (from Table 5), determined from LFL data and credited purge rate, $=38.67 \mathrm{scfm}$ for $45 \mathrm{scfm}$ purge (from Table 5)

Choosing Purge rate, $\mathrm{N}$ bundles and $[\mathrm{Hg}]$ determine the $[\mathrm{Al}]$ such that $\mathrm{Q}=\mathrm{Q}_{\text {limit }}$

$\mathrm{Q}_{\text {limit }} /\{(\mathrm{Q} / \mathrm{A}) *$ Area $* \mathrm{~N}$ bundles $*[\mathrm{Hg}] / 0.002 *(102.64 / 52.53)\}=10^{-1.078 *[\mathrm{Al}]}$

and $(\mathrm{Q} / \mathrm{A}) / \mathrm{Q}_{\text {limit }} *$ Area $* \mathrm{~N}$ bundles * $[\mathrm{Hg}] / 0.002 *(102.64 / 52.53)=10^{1.078 *[\mathrm{Al}]}$

Take $\log _{10}$ of both sides of the equation and solve for [Al]

(4) $[\mathrm{Al}]_{\min }=(1 / 1.078) * \log _{10}\left\{\mathrm{Q} / \mathrm{A} / \mathrm{Q}_{\text {limit }} *\right.$ Area $* \mathrm{~N}$ bundles $\left.*[\mathrm{Hg}] / 0.002 *(102.64 / 52.53)\right\}$ $=(1 / 1.078) * \log _{10}\left\{1.351 \mathrm{scfm} / \mathrm{ft}^{2} / \mathrm{Q}_{\text {limit }} * 5.710 \mathrm{ft}^{2} * \mathrm{~N}\right.$ bundles $\left.*[\mathrm{Hg}] / 0.002 *(102.64 / 52.53)\right\}$ 


\section{Distribution:}

A. B. Barnes, 999-W

D. A. Crowley, 773-43A

S. D. Fink, 773-A

B. J. Giddings, 786-5A

C. C. Herman, 999-W

S. L. Marra, 773-A

A. M. Murray, 773-A

F. M. Pennebaker, 773-42A

S. J. Hensel, 773-42A

W. E. Harris, 704-2H

J. B. Schaade, 704-2H

G. J. Zachman, 225-7H

P. B. Andrews, 704-2H

S. J. Howell, 221-H

J. C. Wallace, 221-H

C. R. Goergen, 704-2H

W. G. Dyer, 704-2H

P. M. Palmer, 221-H

W. H. Clifton, 704-2H

R. A. Eubanks, 221-H

R. G. Brown, 221-H

J. L. Bodkin, 221-H

C. P. Nguyen, 221-H

F. R. Weitz, 221-13H

J. R. Lint, 704-185H

M. C. Chandler, 703-H

G. F. Kessinger, 773-A

E. A. Kyser, 773-A

M. C. Thompson, 773-A

J. E. Laurinat, 773-A

N. M. Askew, 773-42A

J. H. Scogin, 773-A

F. F. Fondeur, 773-A 